\title{
Axillary Lymph Node Status in Multicentric Breast Tumors and Breast Tumors with Nipple Involvement
}

\author{
Murat Cakir Ahmet Tekin Tevfik Kücükkartallar Celalettin Vatansev \\ Faruk Aksoy Adil Kartal Fatma B. Tuncer \\ Department of General Surgery, Meram Medical Faculty, Selcuk University, Konya, Turkey
}

\section{Keywords}

Breast cancer: multicentric, nipple involvement . Axillary lymph nodes

\section{Summary}

Background: Axillary lymph node dissection plays an important role in breast cancer management in terms of staging, prediction of prognosis, determination of adjuvant therapy, and local control of the primary tumor. The objective of this study was to evaluate the axillary lymph node involvement in multicentric breast tumors and breast tumors with nipple involvement in comparison with unifocal tumors. Patients and Methods: We reviewed the records of 267 patients with stage I or IIA disease. The rates of axillary lymph node metastasis (ALNM) in patients with unifocal tumors, multicentric tumors, or nipple involvement were compared. Results: $209(78 \%)$ patients had unifocal tumors, 24 (8\%) had multicentric tumors, and $34(12 \%)$ had nipple involvement. The incidence of ALNM was $9.76 \%$ in patients with unifocal tumors, $24.84 \%$ in patients with multicentric tumors, and $36.71 \%$ in patients with nipple involvement. Hence, the incidence of ALNM was significantly higher in patients with nipple involvement or multicentric tumors than in patients with unifocal tumors. Conclusion: Our data suggest that compared to unifocal tumors, breast tumors with nipple involvement or multiple foci show a significantly higher incidence of ALNM which is a predictor of a poor prognosis.

\section{Introduction}

Surgical treatment is still the primary treatment modality in most patients with breast cancer. Axillary lymph node dissection following mastectomy or breast conserving surgery has

\author{
Schlüsselwörter \\ Mammakarzinom: multizentrisch, Mamillenbeteiligung · \\ Axilläre Lymphknoten
}

\section{Zusammenfassung}

Hintergrund: Die Axilladissektion spielt eine wichtige Rolle im Management des Mammakarzinoms im Sinne von Staging, Prognosestellung, Etablierung der adjuvanten Therapie und lokaler Kontrolle des Primärtumors. Ziel dieser Studie war es, den Stellenwert der axillären Lymphknotenbeteiligung bei multizentrischen Mammakarzinomen und Mammakarzinomen mit Mamillenbeteiligung verglichen mit unifokalen Tumoren zu bestimmen. Patienten und Methoden: Die Unterlagen von 267 Patienten im Stadium I bzw. IIA wurden begutachtet und die Rate der axillären Lymphknotenmetastasierung (ALM) bei Patienten mit unifokalen Tumoren, multizentrischen Tumoren bzw. Mamillenbeteiligung verglichen. Ergebnisse: 209 (78\%) Patienten hatten unifokale Tumoren, $24(8 \%)$ hatten multizentrische Tumoren, und 34 (12\%) zeigten Mamillenbeteiligung. Die ALM-Inzidenz war $9,76 \%$ bei Patienten mit unifokalen Tumoren, $24,84 \%$ bei Patienten mit multizentrischen Tumoren und $36,71 \%$ bei Patienten mit Mamillenbeteiligung. Demzufolge war die ALM-Inzidenz bei Patienten mit Mamillenbeteiligung bzw. multizentrischen Tumoren signifikant höher als bei Patienten mit unifokalen Tumoren. Schlussfolgerung: Unsere Daten deuten an, dass verglichen mit unifokalen Tumoren Mammakarzinome mit Mamillenbeteiligung bzw. multiplen Foci eine signifikant höhere ALM-Inzidenz zeigen, welche prädiktiv für eine schlechte Prognose ist.

been widely used for disease staging, prediction of prognosis, local tumor control, and determination of adjuvant treatment $[1,2]$. The axillary node status, independent of other factors, is the best prognostic marker in patients with breast cancer, and is hence the most important procedure to provide infor-

\section{KARGER \\ Fax +497614520714 \\ Information@Karger.de}

www.karger.com (c) 2012 S. Karger GmbH, Freibur

$1661-3791 / 12 / 0075-0394 \$ 38.00 / 0$

Accessible online at:

www.karger.com/brc
Assoc. Prof. Murat Cakir

Department of General Surgery

Meram Medical Faculty

Selcuk University, 42080 Konya, Turkey

drmuratcakir@hotmail.com 
mation about the prognosis [3-5]. Koscielny et al. [3] showed a correlation between tumor size and the number of positive axillary lymph nodes. However, it has also been stated that this correlation is lost when the size of the primary tumor is less than $3.6 \mathrm{~cm}$ in diameter. Multicentric breast tumors are defined by the presence of 2 or more physically separate tumors in more than 1 quadrant of the same breast. The prevalence of multicentricity reported varies from to 13 to $65 \%$ depending on the definition of multicentricity and the sampling method used to obtain mastectomy specimens [6]. Compared with unifocal tumors, multicentric breast tumors have a higher frequency of lymph node mestastasis [7]. Another tumor characteristic associated with increased axillary lymph node involvement is nipple involvement [8] which has been reported to range from 0 to $58 \%$ [9]. However, we were unable to find a study which compared the rate of axillary lymph node involvement in breast tumors with multiple foci and breast tumors with nipple involvement. In the present study, we therefore explored the frequency of axillary lymph node involvement in unifocal breast tumors, multicentric breast tumors, and breast tumors involving the nipple.

\section{Patients and Methods}

Data pertaining to 850 patients who underwent surgery for breast cancer at the University Hospital of Selcuk University (Meram, Konya, Turkey) between 2006 and 2010 were collected, and the records of 267 female patients who met the study criteria were retrospectively examined. The total number of dissected lymph nodes and the number of metastatic lymph nodes were documented separately and statistically analyzed. Patients were divided into 3 groups: unifocal breast tumors, multicentric breast tumors, and breast tumors with nipple involvement. 2 or more physically separate tumors in different quadrants of the breast were defined as multicentric tumors. Nipple involvement was defined by the presence of tumor in the pathologic examination of the relevant specimen. All patients had stage I or IIA disease according to the TNM classification. All patients had tumors measuring less than $5 \mathrm{~cm}$, and a histopathological diagnosis of infiltrative ductal carcinoma. All surgeries were performed by the same surgical team, and the dissection of the axillary lymph nodes from the tumor specimens was performed by the same pathologist. Patients in whom less than 10 lymph nodes were dissected and those in whom axillary dissection was not performed due to negative sentinel lymph node biopsy were excluded from the study [8]. In our clinic, adequate lymph node dissection is defined as the removal of 10 or more lymph nodes. All tumors were located in the upper quadrant of the breast, and had the same hormone receptor status. The chi square test was used to examine statistical differences between the 3 groups.

\section{Results}

A total of 267 patients aged between 23 and 78 years (median 46 years, 20/standard deviation 11,97) were included in this study. The final pathological evaluation revealed unifocal tumors in $209(78 \%)$ patients, multicentric tumors in $24(8 \%)$ patients, and nipple involvement in 34 (12\%) patients (table 1). The total numbers of dissected axillary lymph nodes and metastatic lymph nodes were calculated for each group and are shown in table 1 . The average number of dissected lymph nodes was 20. In the unifocal tumor group, the total number of dissected lymph node was 3,861, and 377 (9.76\%) of them were found to be metastatic. In the multicentric tumor group, $122(24.84 \%)$ of 491 dissected lymph nodes were metastatic, and in the group with nipple involvement, 228 (36.71\%) of 621 dissected lymph nodes were metastatic. The rate of metastasis was significantly lower in the unifocal tumor group than in the multicentric tumor group $(\mathrm{p}<0.001)$ or the nipple involvement group $(\mathrm{p}<0.001)$. Interestingly, tumors with nipple involvement showed a significantly higher rate of metastasis in the dissected lymph nodes compared to the multicentric tumors $(\mathrm{p}<0.001)$. $\mathrm{p}$ values are shown in table 2 .

\section{Discussion}

Several studies have reported a correlation between tumor size and the number of metastatic axillary lymph nodes. It has also been reported that the number of positive axillary lymph nodes was directly associated with survival. Studies have shown clear evidence for a relationship between axillary lymph node metastases (ALNM) and disease-free survival

\begin{tabular}{lllll}
\hline Patient group & $\begin{array}{l}\text { Patients, } \mathrm{n} \\
(\mathrm{n}=267)\end{array}$ & $\begin{array}{l}\text { Total lymph } \\
\text { nodes removed, } \\
\mathrm{n}\end{array}$ & $\begin{array}{l}\text { Lymph node } \\
\text { metastasis, } \\
\mathrm{n}(\%)\end{array}$ & $\begin{array}{l}\text { Lymph nodes removed } \\
\text { per patient, median } \\
(\min / \mathrm{max}), \mathrm{n}\end{array}$ \\
\hline Single tumor & 209 & 3,861 & $377(9.76)$ & $18.00(10 / 40)$ \\
Multicentric tumor & 24 & 491 & $122(24.84)$ & $20.04(10 / 34)$ \\
Nipple invasion & 34 & 621 & $228(36.71)$ & $20.30(10 / 36)$ \\
\hline
\end{tabular}

Table 1. Number of dissected and positive lymph nodes for the 3 patient groups

Table 2. $p$ values for the 3 patient groups

\begin{tabular}{llll}
\hline Overall $\mathrm{p}$ value & \multicolumn{2}{l}{ Between-group p value } & \\
\cline { 2 - 4 } & $\begin{array}{l}\text { single tumor/ } \\
\text { multicentric tumor }\end{array}$ & $\begin{array}{l}\text { single tumor/ } \\
\text { nipple invasion }\end{array}$ & $\begin{array}{l}\text { multicentric tumor/ } \\
\text { nipple invasion }\end{array}$ \\
\hline$<0.001$ & $<0.001$ & $<0.001$ & $<0.001$ \\
\hline
\end{tabular}


[10-12]. In our study, we examined axillary lymph node involvement for tumors with similar histolopathologic characteristics and measuring $5 \mathrm{~cm}$ or less. Many studies have found a correlation between tumor size and ALNM. 10-year survival rates for patients with breast cancer have been reported to be over $70 \%$ for patients without ALNM. However, this rate decreases to $50 \%$ in patients with $1-3$ ALNM, 35\% in patients with 4-10 ALNM, 20\% in patients with 11-20 ALNM, and $17 \%$ in patients with more than 20 ALNM [13]. Based on this data, we can conclude that the prognosis is less favorable in patients with multicentric breast cancer or breast cancer involving the nipple [13]. Our results showed that by controlling for tumor size, breast cancer with multiple foci or nipple involvement has a significantly higher frequency of ALNM than unifocal tumors of the same size.

The most important predictors of 10- and 20-year survival are distant metastasis and the number of metastatic axillary lymph nodes. However, physical examination alone is not sufficient in determining the extent of ALNM and predicting survival and yields a $25-31 \%$ false-positive and $23-33 \%$ falsenegative rate.

Several factors are associated with axillary lymph node involvement in patients with breast cancer. These factors include tumor size, histological tumor characteristics, lymphatic or vascular invasion, tumor grade, neovascularization of the tumor, S phase fraction, DNA aneuploidy, and extensive intraductal component [13-15]. The most important and best proven of the above factors, which also gives an idea about prognosis, is tumor size. In our study, tumor size was standardized by only including stage I and IIA tumors. Also, only infiltrative ductal carcinomas were included which made this study more optimal.

Almost $50 \%$ of patients with breast cancer can now be diagnosed before stage II. The rate of axillary lymph node involvement at the time of diagnosis is about $30-35 \%[16,17]$. The incidence of ALNM is $0-1 \%$ in patients with ductal carcinoma in situ, 3-5\% in patients at stage IA, $10-17 \%$ in patients at stage $\mathrm{T} 1 \mathrm{~B}, 23-48 \%$ in patients at stage $\mathrm{T} 2$, and $29-64 \%$ in patients at stage T3 $[17,18]$. We detected that breast tumors with multiple foci or nipple involvement had a higher frequency of ALNM than unifocal tumors, and breast tumors with nipple involvement were associated with a higher ALNM frequency than multifocal tumors $(\mathrm{p}<0.001)$.

In summary, breast tumors with a higher rate of axillary lymph node metastasis have a poorer prognosis. Our results showed that breast tumors with nipple involvement and multicentric tumors have a significantly higher incidence of ALNM than unifocal tumors, which leads to the conclusion that these patient groups carry a less favorable prognosis.

\section{Disclosure Statement}

We the authors have no conflicts of interest to declare which include financial or personal relationships.

\section{References}

1 Keshtgar MRS, Baum M: Axillary dissection over the years: where to from here? World J Surg 2001;25:761-766.

2 Carter CL, Allen C, Henson DE: Relation of tumor size, lymph node status and survival in 24,740 breast cancer cases. Cancer 1989;63:181-187.

$\checkmark 3$ Koscielny S, Arriagada R, Adolfsson J, Fornander $\mathrm{T}$, Bergh J: Impact of tumor size on axillary involvement and distant dissemination in breast cancer. Br J Cancer 2009;101:902-907.

4 Xia Q, Shi YX, Liu DG, Jiang WQ: (Clinicopathological characteristics of male breast cancer: analysis of 25 cases at a single institution). Nan Fang Yi Ke Da Xue Xue Bao 2011;31:1469-1473.

5 Rugină VG, Mihalcea D, Pricop F: (The lymph nodes status - prognostic factor in breast cancer) Rev Med Chir Soc Med Nat Iasi 2011;115:839-844.

6 Vlastos G, Rubio IT, Mirza NQ, Newman LA, Aurora R, Alderfer J, Buzdar AU, Singletary SE: Impact of multicentricity on clinical outcome in patients with T1-2, N0-1, M0 breast cancer. Ann Surg Oncol 2000;7:581-587.

7 Andea AA, Bouwman D, Wallis T, Visscher DW Correlation of tumor volume and surface area with lymph node status in patients with multifocal/multicentric breast carcinoma. Cancer 2004;100:20-27.
8 Cetintas SK, Kurt M, Ozkan L, Engin K, Gökgöz S, Tașdelen I: Factors influencing axillary node metastasis in breast cancer. Tumori 2006;92:416-422.

$\checkmark$ Brachtel EF, Rusby JE, Michaelson JS, Chen LL, Muzikansky A, Smith BL, Koerner FC: Occult nipple involvement in breast cancer: clinicopathologic findings in 316 consecutive mastectomy specimens. J Clin Oncol 2009;27:4948-4954.

10 Kiricuta CI, Tausch J: A mathematical model of axillary lymph node involvement based on 1,446 complete axillary dissections in patients with breast carcinoma. Cancer 1992;69:2496-2501.

11 Elezoğlu B, Tolunay Ș, Tașdelen İ: Histopathologic characteristics of sentinel lymph node biopsy in breast carcinoma: Uludağ University Faculty of Medicine Experience. J Med Sci 2011;31:13241329.

12 Fisher B, Redmond C, Fisher ER, Caplan R: Relative worth of estrogen or progesterone receptor and pathologic characteristics of differentiation as indicators of prognosis in node negative breast cancer patients: findings from National Surgical Adjuvant Breast and Bowel Project Protocol B-06. J Clin Oncol 1988;6:1076-1087.

13 Sayek İ, Cam R: Meme kanserlerinde prognostik faktörler. Temel cerrahi 3. baskı. 2003;953-958.
14 Mansour EG, Gray R, Shatila AH, Tormey DC, Cooper MR, Osborne CK, Falkson G: Survival advantage of adjuvant chemotherapy in high risk node-negative breast cancer: ten-year analysis. An intergroup study. J Clin Oncol 1998;16:3486-3492.

15 Gervasoni JE, Taneja C: Axillary dissection in the context of the biology of lymph node metastases. Am J Surg 2000;180:278-283.

16 Bland KI, Menck HR, Scott-Conner CE, Morrow M, Winchester DJ, Winchester DP: The National Cancer Data Base 10-year survey of breast cancer treatment at hospitals in the United States. Cancer 1998;83:1262-1273.

17 Kelten C, Sen Turk N, Kesen Z, Akbulut M, Duzcan E. Turkiye Klinikleri J Med Sci 2011;31:225-229.

18 Coskun F, Özer M, Dincturk C: Immunomorphological reactions of regional nodes in mammary carcinoma and prognosis (study of 100 cases) Turkiye Klinikleri J Med Res 1990;8:283-289. 